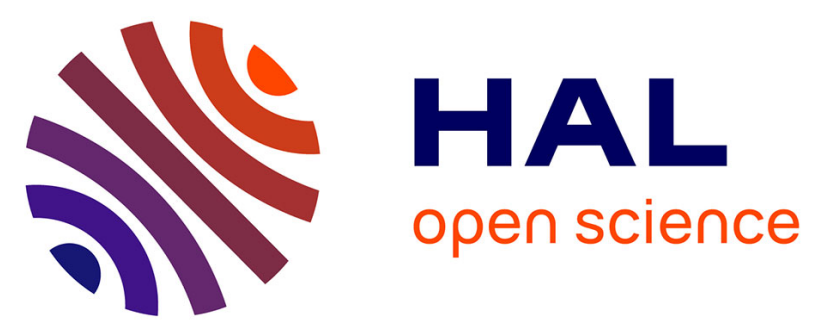

\title{
Understanding Early Post-Mortem Biochemical Processes Underlying Meat Color and pH Decline in the Longissimus thoracis Muscle of Young Blond d'Aquitaine Bulls Using Protein Biomarkers.
}

Mohammed Gagaoua, Claudia Terlouw, Didier Micol, Abdelghani Boudjellal, Jean-François J.-F. Hocquette, Brigitte Picard

\section{To cite this version:}

Mohammed Gagaoua, Claudia Terlouw, Didier Micol, Abdelghani Boudjellal, Jean-François J.F. Hocquette, et al.. Understanding Early Post-Mortem Biochemical Processes Underlying Meat Color and pH Decline in the Longissimus thoracis Muscle of Young Blond d'Aquitaine Bulls Using Protein Biomarkers.. Journal of Agricultural and Food Chemistry, 2015, 63 (30), pp.6799-6809. 10.1021/acs.jafc.5b02615 . hal-01191442

\author{
HAL Id: hal-01191442 \\ https://hal.science/hal-01191442
}

Submitted on 1 Sep 2015

HAL is a multi-disciplinary open access archive for the deposit and dissemination of scientific research documents, whether they are published or not. The documents may come from teaching and research institutions in France or abroad, or from public or private research centers.
L'archive ouverte pluridisciplinaire HAL, est destinée au dépôt et à la diffusion de documents scientifiques de niveau recherche, publiés ou non, émanant des établissements d'enseignement et de recherche français ou étrangers, des laboratoires publics ou privés. 


\title{
Understanding Early Post-Mortem Biochemical Processes Underlying Meat Color and pH Decline in the Longissimus thoracis Muscle of Young Blond d'Aquitaine Bulls Using Protein Biomarkers
}

\author{
Mohammed Gagaoua, ${ }^{\dagger, \ddagger}$ E. M. Claudia Terlouw, ${ }^{\dagger, \ddagger}$ Didier Micol, ${ }^{\dagger, \ddagger}$ Abdelghani Boudjellal, ${ }^{\S}$ \\ Jean-François Hocquette, ${ }^{\dagger, \dagger}$ and Brigitte Picard ${ }^{*, \dagger, \dagger}$ \\ ${ }^{\dagger}$ INRA, UMR 1213 Herbivores, F-63122 Saint-Genès Champanelle, France \\ ${ }^{\ddagger}$ Clermont Université, VetAgro Sup, UMR 1213 Herbivores, B.P. 10448, F-63000 Clermont-Ferrand, France \\ ${ }^{\S}$ Equipe Maquav, INATAA, Université Frères Mentouri Constantine, Route de Ain El-Bey, 25000 Constantine, Algeria
}

\begin{abstract}
Many studies on color biochemistry and protein biomarkers were undertaken in post-mortem beef muscles after $\geq 24$ hours. The present study was conducted on Longissimus thoracis muscles of 21 Blond d'Aquitaine young bulls to evaluate the relationships between protein biomarkers present during the early post-mortem and known to be related to tenderness and $\mathrm{pH}$ decline and color development. $\mathrm{pH}$ values at $45 \mathrm{~min}, 3 \mathrm{~h}$, and $30 \mathrm{~h}$ post-mortem were correlated with three, seven, and six biomarkers, respectively. $L^{*} a^{*} b *$ color coordinates $24 \mathrm{~h}$ post-mortem were correlated with nine, five, and eight protein biomarkers, respectively. Regression models included Hsp proteins and explained between 47 and 59\% of the variability between individuals in $\mathrm{pH}$ and between 47 and $65 \%$ of the variability in $L^{*} a^{*} b^{*}$ color coordinates. Proteins correlated with $\mathrm{pH}$ and/or color coordinates were involved in apoptosis or had antioxidative or chaperone activities. The main results include the negative correlations between $\mathrm{pH}_{45}$ min, $\mathrm{pH}_{3 \mathrm{~h}}$ and $\mathrm{pH}_{\mathrm{u}}$ and $\mathrm{Prdx6}$, which may be explained by the antioxidative and phospholipase activities of this biomarker. Similarly, inducible Hsp70-1A/B and $\mu$-calpain were correlated with $L^{*} a^{*} b *$ coordinates, due to the protective action of Hsp70-1A/ $\mathrm{B}$ on the proteolytic activities of $\mu$-calpain on structural proteins. Correlations existed further between MDH1, ENO3, and LDH-B and $\mathrm{pH}$ decline and color stability probably due to the involvement of these enzymes in the glycolytic pathway and, thus, the energy status of the cell. The present results show that research using protein indicators may increase the understanding of early post-mortem biological mechanisms involved in $\mathrm{pH}$ and beef color development.
\end{abstract}

KEYWORDS: beef, Blond d'Aquitaine, meat color, $\mathrm{pH}$, protein biomarkers, post-mortem, biological mechanisms

\section{INTRODUCTION}

Meat color is an organoleptic characteristic with a major influence on purchase decisions by consumers. ${ }^{1,2}$ Color is influenced by the content and physicochemical state of myoglobin and by the meat structure. $^{3,4}$ The latter is directly related to the ultimate $\mathrm{pH}$ : at high ultimate $\mathrm{pH}$, muscle fibers are more tightly packed together as a result of increased water-holding capacity of muscle protein. As a consequence, its surface will scatter light less and the meat will appear darker., ${ }^{3,4}$ The rate of post-mortem $\mathrm{pH}$ decline influences biochemical reactions and structural characteristics of the muscles and may also influence color.,

Myoglobin $(\mathrm{Mb})$ plays further a central role in meat color. $\mathrm{Mb}$ content depends not only on the muscle but also on other factors such as breed, age, and diet. ${ }^{1,2}$ Slow-twitch oxidative muscle fibers are rich in $\mathrm{Mb}$ compared to fast-twitch glycolytic fibers. ${ }^{3} \mathrm{Mb}$ contains a hemeatin nucleus with a central iron atom. The iron atom of $\mathrm{Mb}$ may be reduced (DeoxyMb; purple), oxygenized $\left(\mathrm{MbO}_{2}\right.$; bright red), or oxidized (MetMb; brown). ${ }^{7}$ The interconversion of the three forms in fresh beef depends on the levels of antioxidants and pro-oxidants present. ${ }^{8}$ Loss of reducing activity in meat during storage is due to a combination of factors including $\mathrm{pH}$ decline, depletion of required substrates and cofactors particularly $\mathrm{NADH}$, the presence of secondary lipid oxidation products, $\mathrm{pH}$-induced denaturation of the enzymes, and ultimately the complete loss of structural integrity and functional properties of the mitochondria. ${ }^{1,8,9}$
Comparative transcriptomic and proteomic studies have revealed biochemical pathways involved in meat sensory qualities, including tenderness, juiciness, and water-holding capacity. ${ }^{10-13}$ These pathways are related to myofibril structure, proteolysis, heat stress, oxidative stress resistance, apoptosis, or energy metabolism. ${ }^{12,14,15}$ At least part of these pathways may also be related to meat color development and stability, particularly those related to oxidative processes and the redox status of the muscle, to energy metabolism, and consequently to the status of the $\mathrm{NADH}$ pool and $\mathrm{pH}$ decline, and to apoptosis. ${ }^{16-19}$

Such transcriptomic and proteomic studies have allowed our laboratory to establish a list of proteins, known as biomarkers, potentially predictive of certain sensory qualities. ${ }^{13}$ Many studies on color biochemistry and protein biomarkers were undertaken in post-mortem beef muscles after $\geq 24 \mathrm{~h}$ post-mortem. The present study uses the earlier identified biomarkers to evaluate the relationships between protein status in the early post-mortem period, subsequent $\mathrm{pH}$ decline, and beef color as evaluated by $L^{*} a^{*} b^{*}$ coordinates. The study uses a high through-put technique and was conducted on young bulls of the French Blond

Received: $\quad$ May 26, 2015

Revised: July 9, 2015

Accepted: July 9, 2015 
d'Aquitaine (BA) breed, characterized by good muscle development, producing tender meat ${ }^{20}$ but with a relatively pale color.

\section{MATERIALS AND METHODS}

Animals and Sampling. This study was part of the European ProSafeBeef project (FOOD-CT-2006-36241). Twenty-one Blond d'Aquitaine (BA) young bulls reared under intensive conditions and finished over two consecutive years (two replicated groups) were used. At 12 months of age, they were subjected to a 105 day finishing period until slaughter. Diets consisted of concentrate $(75 \%)$ and straw (25\%). Before slaughter, all animals were food deprived for $24 \mathrm{~h}$ and had free access to water. The animals at a live weight of $635 \pm 52 \mathrm{~kg}$ were slaughtered at the experimental abattoir of the INRA Research center in compliance with the current ethical guidelines for animal welfare. Bulls were directly transported $(4.5 \pm 0.1 \mathrm{~min})$ in a lorry $(3 \times 2 \mathrm{~m}$ livestock compartment) from the experimental farm to the experimental abattoir situated $2 \mathrm{~km}$ from the rearing building, with two bulls of the same home pen per transport to avoid social isolation stress. After unloading, they were slaughtered within $3 \mathrm{~min}^{21}$ The mean hot carcass weight was $410 \pm 42 \mathrm{~kg}$ (range from 337 to $500 \mathrm{~kg}$ ). The carcasses were not electrically stimulated, and they were chilled and stored at $4{ }^{\circ} \mathrm{C}$ from $1 \mathrm{~h}$ until $24 \mathrm{~h}$ post-mortem. Longissimus thoracis (LT, mixed fast oxidoglycolytic) muscle samples were excised from the left side of the sixth rib $30 \mathrm{~min}$ post-mortem and frozen in liquid nitrogen before storage at $-80{ }^{\circ} \mathrm{C}$ until protein extractions for Dot-Blot analysis or myosin heavy chain (MyHC) quantification.

pH Measurements. For $\mathrm{pH}_{45 \text { min }}$ measurement, biopsies were made from the carcasses (10th rib), whereas $\mathrm{pH}_{3 \mathrm{~h}}$ and ultimate $\mathrm{pH}$ $\left(30 \mathrm{~h} ; \mathrm{pH}_{\mathrm{u}}\right)$ were measured directly on the carcass (right side). $\mathrm{pH}$ was determined as in Bourguet et al. ${ }^{21}$ Briefly, $2 \mathrm{~g}$ of each LT sample excised $45 \mathrm{~min}$ after slaughter was immediately homogenized in $18 \mathrm{~mL}$ of $5 \mathrm{mM}$ sodium iodoacetate and stored at $4{ }^{\circ} \mathrm{C}$. The $\mathrm{pH}$ of the homogenate was measured the following day at $6{ }^{\circ} \mathrm{C}$. For $\mathrm{pH}_{3 \mathrm{~h}}$ and $\mathrm{pH}_{w}$ the $\mathrm{pH}$ was recorded directly on the carcass between the sixth and seventh rib using a $\mathrm{pH}$ meter (Hanna Instruments, HI9025) equipped with a glass electrode suitable for meat penetration. For each time point, five measurements were made (positioned on a horizontal line with about $1.5 \mathrm{~cm}$ between two measurements).

Meat Color. The LT muscle was excised from the stored carcass at the level of the sixth rib thoracis vertebra $24 \mathrm{~h}$ post-mortem to determine color attributes. Instrumental meat color measurements were recorded for lightness $\left(L^{*}=\right.$ measures light reflected), redness $\left(a^{*}=\right.$ measures positive red and negative green), and yellowness $\left(b^{*}=\right.$ measures positive yellow and negative blue) directly on the tissue of the muscle using a Minolta CR-300 chromameter (Minolta Co., Ltd., Osaka, Japan), with a $0^{\circ}$ viewing angle, $\mathrm{C}$ illuminant, and $8 \mathrm{~mm}$ measurement aperture. Fresh-cut slices of muscle of not less than $2.5 \mathrm{~cm}$ thick and overwrapped were left on a polystyrene tray to refrigerate at $1{ }^{\circ} \mathrm{C}$ for $1 \mathrm{~h}$ to allow blooming. Calibration was performed by using standard white tiles $(Y=93.58, x=0.3150$, and $y=0.3217)$ prior to color determination. Three replicate measurements were taken, and an average value was used for analysis. Color coordinates were expressed as $L^{*}, a^{*}, b^{*}$ following the CIE- $L * a * b *$ system.

Protein Extractions. Total protein extractions were performed to use subsequently the soluble fractions for Dot-Blot analysis according to the method of Bouley et al..$^{22}$ Briefly, $80 \mathrm{mg}$ of muscle was homogenized in a denaturation/extraction buffer containing $8.3 \mathrm{M}$ urea, $2 \mathrm{M}$ thiourea, 1\% DTT, and 2\% CHAPS. After $30 \mathrm{~min}$ of centrifugation at $10000 \mathrm{~g}$ at $8{ }^{\circ} \mathrm{C}$, the supernatant was stored at $-20^{\circ} \mathrm{C}$ until use. The protein concentrations of the extracts were determined according to the Bradford method ${ }^{23}$ using the Bio-Rad protein assay. Bovine serum albumin (BSA) at a concentration of $1 \mathrm{mg} / \mathrm{mL}$ was used as standard.

Dot-Blot Analysis. The abundances of 18 proteins (including intact molecules and their fragments) corresponding to five different biological functions (Table 1), muscle fiber structure (actin, MyBP-H, CapZ- $\beta$, and MyLC-1F), metabolism (ENO3, LDHB, and $\mathrm{MDH} 1$ ), proteolysis ( $\mu$-calpain), oxidative resistance (DJ-1, Prdx6, and SOD1), and heat shock proteins ( $\alpha$ B-crystallin, Hsp20, Hsp27, Hsp40, Hsp70-1A/B, Hsp70-8, and Hsp70-Grp75), were determined using the Dot-Blot
Table 1. Eighteen Protein Biomarkers Quantified Using the Dot-Blot Technique ${ }^{a}$

\begin{tabular}{|c|c|c|c|}
\hline $\begin{array}{l}\text { protein biomarker } \\
\text { name }(\text { gene })^{b}\end{array}$ & $\begin{array}{l}\text { UniProtKB } \\
\text { ID }\end{array}$ & $\begin{array}{c}\text { monoclonal (Mo) or } \\
\text { polyclonal (Po) antibody ref }\end{array}$ & $\begin{array}{l}\text { antibody } \\
\text { dilution }\end{array}$ \\
\hline \multicolumn{4}{|l|}{ heat shock proteins } \\
\hline $\begin{array}{l}\alpha \mathrm{B} \text {-crystallin } \\
\quad(C R Y A B)\end{array}$ & P02511 & $\begin{array}{l}\text { Mo anti-bovine Assay Designs } \\
\text { SPA-222 }\end{array}$ & $1 / 500$ \\
\hline Hsp20 (HSPB6) & O14558 & $\begin{array}{l}\text { Mo anti-human Santa Cruz } \\
\text { HSP20-11:SC51955 }\end{array}$ & $1 / 200$ \\
\hline Hsp27 (HSPB1) & P04792 & $\begin{array}{l}\text { Mo anti-human Santa Cruz } \\
\text { HSP27 (F-4):SC13132 }\end{array}$ & $1 / 3000$ \\
\hline Hsp40 (DNAJA1) & P31689 & $\begin{array}{l}\text { Mo anti-human Santa Cruz } \\
\text { HSP40-4 (SPM251): } \\
\text { SC-56400 }\end{array}$ & $1 / 250$ \\
\hline $\begin{array}{c}\text { Hsp70-1A/B } \\
(H S P A 1 B)\end{array}$ & P08107 & $\begin{array}{l}\text { Mo anti-human Abnova } \\
\text { HSPA1B (M02), clone 3B7 }\end{array}$ & $1 / 2000$ \\
\hline Hsp70-8 (HSPA8) & P11142 & $\begin{array}{l}\text { Mo anti-bovine Santa Cruz } \\
\text { HSC70 (BRM22):SC-59572 }\end{array}$ & $1 / 250$ \\
\hline $\begin{array}{l}\text { Hsp70-Grp75 } \\
\text { (HSPA9) }\end{array}$ & P38646 & $\begin{array}{l}\text { Mo anti-human RD Systems } \\
\text { clone } 419612\end{array}$ & $1 / 250$ \\
\hline \multicolumn{4}{|l|}{ metabolism } \\
\hline enolase 3 (ENO3) & P13929 & $\begin{array}{l}\text { Mo anti-human Abnova Eno3 } \\
\text { (M01), clone 5D1 }\end{array}$ & $1 / 45000$ \\
\hline LDH-B (LDHB) & P07195 & $\begin{array}{l}\text { Mo anti-human Novus LDHB } \\
\text { NB110-57160 }\end{array}$ & $1 / 50000$ \\
\hline MDH1 (MDH1) & P40925 & $\begin{array}{l}\text { Mo anti-pig Rockland } \\
100-601-145\end{array}$ & $1 / 1000$ \\
\hline \multicolumn{4}{|l|}{ structure } \\
\hline CapZ- $\beta(C A P Z B)$ & P47756 & $\begin{array}{l}\text { Mo anti-human Abnova } \\
\text { CAPZB (M03), clone } 4 \mathrm{H} 8\end{array}$ & $1 / 250$ \\
\hline$\alpha$-actin $(A C T A 1)$ & P68133 & $\begin{array}{l}\text { Mo anti-rabbit Santa Cruz } \\
\alpha \text {-actin (5C5):SC-58670 }\end{array}$ & $1 / 1000$ \\
\hline MyLC-1F (MYL1) & P05976 & $\begin{array}{l}\text { Po anti-human Abnova MYL1 } \\
\text { (A01) }\end{array}$ & $1 / 1000$ \\
\hline МyBР-H (MYBPH) & Q13203 & $\begin{array}{l}\text { Mo anti-human Abnova } \\
\text { MYBPH (M01), clone 1F11 }\end{array}$ & $1 / 4000$ \\
\hline \multicolumn{4}{|l|}{ oxidative resistance } \\
\hline DJ-1 (PARK7) & Q99497 & $\begin{array}{l}\text { Po anti-human Santa Cruz } \\
\text { DJ-1 (FL-189):SC-32874 }\end{array}$ & $1 / 250$ \\
\hline Prdx6 (PRDX6) & P30041 & $\begin{array}{l}\text { Mo anti-human Abnova } \\
\text { PRDX6 (M01), clone } \\
\text { 3A10-2A11 }\end{array}$ & $1 / 500$ \\
\hline SOD1 (SOD1) & P00441 & $\begin{array}{l}\text { Po anti-rat Acris SOD1 } \\
\text { APO3021PU-N }\end{array}$ & $1 / 1000$ \\
\hline \multicolumn{4}{|l|}{ proteolysis } \\
\hline$\mu$-calpain (CAPN1) & P07384 & $\begin{array}{l}\text { Mo anti-bovine Alexis } \mu \text { - } \\
\text { calpain 9A4H8D3 }\end{array}$ & $1 / 1000$ \\
\hline
\end{tabular}

${ }^{a}$ The suppliers and conditions for each primary antibody used in this study are given. ${ }^{b}$ For protein marker abbreviations see Table 2 .

technique. ${ }^{14,15}$ Compared to Western blot, Dot-Blot is a fast technique, but with a similar coefficient of variation inter- and intra-assay (10\%). Optimal dilution ratios of the antibodies were determined, using the conditions indicated by the supplier and adapted to bovine muscle samples (Table 1). For that, Western blots were used to check the specificity of all antibodies. An antibody was considered specific against the studied protein when only one band at the expected molecular weight was detected by Western blot. Western blots with all primary antibodies show that all of the antibodies used bound specifically to the bovine protein with the expected theoretical molecular weight.

Conditions retained and suppliers for all primary antibodies dilutions are summarized in Table 1 . Protein extracts $(15 \mu \mathrm{g})$ of each of the 21 muscle samples were spotted (four replications per muscle sample) on a nitrocellulose membrane with the Minifold I Dot-Blot apparatus from Schleicher \& Schuell Biosciences (Germany) in a random order on the 96-spots membrane. In addition, a mixed standard sample $(15 \mu \mathrm{g})$ was deposited for data normalization as reported by Guillemin et al. ${ }^{\text {I5 }}$ The Dot-Blot membrane was air-dried for 5 min, blocked in $10 \%$ milk blocking buffer at $37{ }^{\circ} \mathrm{C}$ for $20 \mathrm{~min}$, and then hybridized and incubated with the specific primary antibody of each protein (Table 1). Infrared 

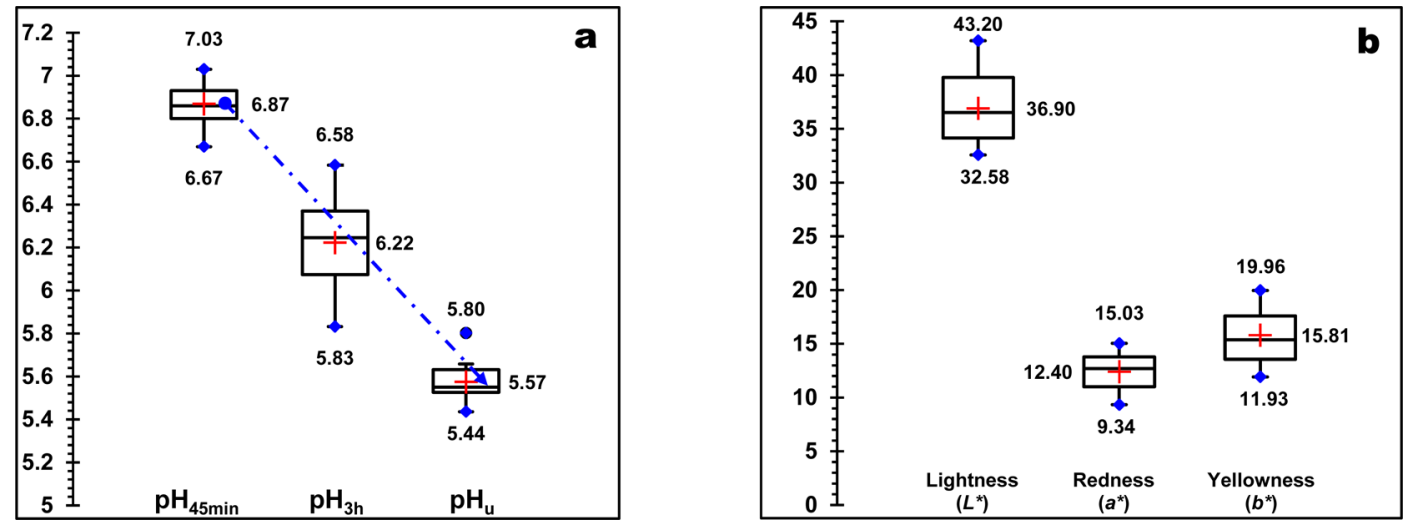

Figure 1. Average means of (a) $\mathrm{pH}\left(45 \mathrm{~min}, 3 \mathrm{~h}\right.$, and ultimate (u)) and (b) $L^{*} a^{*} b^{*}$ meat color parameters of Longissimus thoracis muscle of Blond d'Aquitaine young bulls $(n=21)$. The parameters are presented as box-whiskers plots: for each variable independently, the central point represents the average value calculated over all of the observations. The box represents the average value \pm one standard deviation; the bar represents the minimum and maximum values.

fluorescence detection was then used for quantification of the relative protein abundances. Subsequently, the membranes were scanned by the Odyssey scanner (LI-COR Biosciences) at $800 \mathrm{~nm}$. The relative protein abundances for each sample are given in arbitrary units.

Electrophoresis and Quantification of Myosin Heavy Chain Isoforms. Three other biomarkers corresponded to MyHC and were determined according to the method of Picard et al. ${ }^{24}$ using an adequate SDS-PAGE and expressed in percentage. Briefly, $100 \mathrm{mg}$ of frozen muscle was ground in $5 \mathrm{~mL}$ of extraction buffer solution containing $0.5 \mathrm{M} \mathrm{NaCl}$, $20 \mathrm{mM}$ sodium pyrophosphate, $50 \mathrm{mM}$ Tris, $1 \mathrm{mM}$ EDTA, and $1 \mathrm{mM}$ dithiothreitol. After $10 \mathrm{~min}$ at $4{ }^{\circ} \mathrm{C}$ on ice, the sample was centrifuged for $5 \mathrm{~min}$ at $5000 \mathrm{~g}$. Following centrifugation, the supernatant was diluted 1:1 $(\mathrm{v} / \mathrm{w})$ with glycerol at $87 \%$ and stored at $-20^{\circ} \mathrm{C}$ until use. The samples were then mixed with an equal volume of loading buffer containing $4 \%$ SDS (w/v), $125 \mathrm{mM}$ Tris, $\mathrm{pH} 6.8,20 \%$ glycerol (v/v), $10 \%$ $\beta$-mercaptoethanol $(\mathrm{v} / \mathrm{v})$, and $0.02 \%$ pyronin $\mathrm{Y}(\mathrm{w} / \mathrm{v})$. The proteins were separated using $9.2 \%$ polyacrylamide gels. After staining, the gels were scanned, and the proportions of the different MyHCs bands were quantified by densitometry with ImageQuant Software 5500 (Amersham Biosciences/GE Healthcare). The band quantification revealed the existence of MyHC-IIb isoforms in only some animals (4 animals of 21). Consequently, MyHC-IIb percentages were totaled with those of MyHCIIx, creating a new variable "MyHC-IIx+b" (fast glycolytic fibers).

Statistical Analysis. For descriptive statistics, raw data were used. For statistical analyses all data were standardized for replicate using the Proc Standard of SAS 9.2 to obtain $Z$ scores. A $Z$ score represents the number of standard deviations each observation is relative to the mean of the corresponding animal: $Z=((x-\mu) / \sigma)$, where $\mathrm{x}$ is the raw value, $\mu$ is the mean of the population, and $\sigma$ is the standard deviation of the same population.

The PROC CORR of SAS was used to determine the Pearson's correlation coefficients between the 21 biomarkers with $\mathrm{pH}$ and CIE$L^{*} a^{*} b^{*}$ color coordinates. Correlation values were considered significant at $P<0.05$.

For each $\mathrm{pH}$ value and each color coordinate, a principal component analysis (PCA) was carried out using PROC PRINCOMP of SAS, using only the correlated biomarkers. PCA aimed to illustrate visually the correlated biomarkers with $\mathrm{pH}$ and color coordinates. The overall Kaiser's measures of sampling adequacies of the performed PCAs were $>0.68$ for $\mathrm{pH}$ parameters and $>0.80$ for $L^{*} a^{*} b^{*}$ color coordinates.

Multiple regression analyses were performed using PROC REG of SAS to create best models (maximal adjusted $R^{2}$ ) for $\mathrm{pH}$ and color coordinates (as dependent variables) using the 21 protein biomarkers (as independent variables). Partial $R$-squares and significance of each retained variable are given for the models. Regression analyses were further conducted on $L^{*}, a^{*}$, and $b^{*}$ color coordinates to study specifically the relationships with $\mathrm{pH}$ values and muscle fiber type composition.
The absence of collinearity was systematically verified for each model, by producing condition indices and variance proportions using the COLLIN procedure of SAS. Variables were identified as collinear if they possessed both a high condition index $>10$ and a proportion of variation $>0.5$ for two or more traits.

\section{RESULTS}

pH Parameters, Color Traits, and Biomarker Abundances. Average means of $\mathrm{pH}$ and color parameters are shown in Figure 1. $\mathrm{pH}$ measured $45 \mathrm{~min}$ post-mortem was $6.87( \pm 0.10)$ and declined to $6.22( \pm 0.20) 3 \mathrm{~h}$ post-mortem, reaching 5.57 $( \pm 0.08) 30 \mathrm{~h}$ post-mortem (Figure 1a). Mean color coordinates were $36.9( \pm 3.32)$ for lightness $\left(L^{*}\right), 12.40( \pm 1.74)$ for redness $\left(a^{*}\right)$, and $15.81( \pm 2.65)$ for yellowness $\left(b^{*}\right)$ (Figure $\left.1 b\right)$. Relative abundances of biomarkers expressed in arbitrary units or in percentage $(\mathrm{MyHC})$ are summarized in Table 2. The LT muscle was characterized by $19.2 \%( \pm 3.6)$ of type I fibers, $3.9 \%$ $( \pm 4.3)$ of IIa, and $56.9 \%( \pm 4.0)$ of IIx/b.

Relationships between Biomarkers and $\mathrm{pH}$ Parameters. $\mathrm{pHu}$ was correlated with $\mathrm{pH}_{45 \text { min }}(r=0.47 ; P<0.05)$ and $\mathrm{pH}_{3 \mathrm{~h}}(r=0.59, P<0.01) . \mathrm{pH}_{45}$ min was correlated with $\mathrm{pH}_{3 \mathrm{~h}}$ $(r=0.47, P<0.05) . \mathrm{pH}$ was further correlated with 11 biomarkers (Figure 2a). Prdx6 was negatively correlated with $\mathrm{pH}_{45 \text { min }}(r=-0.49, P<0.05), \mathrm{pH}_{3 \mathrm{~h}}(r=-0.47, P<0.05)$, and $\mathrm{pH}_{\mathrm{u}}(r=-0.66, P<0.01)$. Hsp70-Grp75 and DJ-1 were negatively correlated with both $\mathrm{pH}_{3 \mathrm{~h}}(r=-0.45$ and -0.56 , $P<0.05$, respectively $)$ and $\mathrm{pH}_{\mathrm{u}}(r=-0.45$ and $-0.43, P<0.05$, respectively). Actin was negatively correlated with $\mathrm{pH}_{45}$ min and $\mathrm{pH}_{\mathrm{u}}(r=-0.40, P<0.05) . \mathrm{MDH} 1$ was negatively correlated $(r=-0.48, P<0.05)$ with $\mathrm{pH}_{45 \text { min }}$ only. MyBP-H $(r=-0.43)$, ENO3 $(r=-0.46)$, LDH-B $(r=-0.43)$, and Hsp20 $(r=$ $-0.50)$ were significantly $(P<0.05)$ and negatively correlated with $\mathrm{pH}_{3}$. MyHC-IIx/b (positively) and CapZ- $\beta$ (negatively) were correlated with ultimate $\mathrm{pH}$ only $(r=0.40$ and -0.55 , $P<0.05$, respectively). The biomarkers that were significantly correlated with $\mathrm{pH}$ were introduced into PCAs (Figure 3). The first two PCA axes explained 80.7, 69.4, and $73.2 \%$ of the variability between animals of $\mathrm{pH}_{45}$ min $\left(\right.$ Figure $3 \mathrm{a}$ ), $\mathrm{pH}_{3 \mathrm{~h}}$ (Figure 3b), and $\mathrm{pH}_{\mathrm{u}}$ (Figure $\left.3 \mathrm{c}\right)$, respectively.

Regression Analyses of pH Parameters. The multiple linear regression analyses, using $\mathrm{pH}$ parameters as dependent and biomarker abundances as independent variables, revealed significant relationships (Table 3; Figure 4). For $\mathrm{pH}_{45 \text { min }}$ 47\% of the variability $(P<0.01)$ was explained by MDH1 and actin 
Table 2. Mean and Standard Deviation (SD) of the 21

Protein Biomarkers Quantified in Longissimus thoracis Muscle of Blond d'Aquitaine Young Bulls

\begin{tabular}{lll}
\multicolumn{1}{c}{ variable } & mean & SD \\
heat shock proteins & & \\
$\alpha$ B-crystallin & 15.61 & 4.23 \\
Hsp20 & 17.39 & 3.55 \\
Hsp27 & 19.04 & 5.33 \\
Hsp40 & 17.40 & 2.47 \\
Hsp70-1A/B & 17.40 & 3.10 \\
Hsp70-8 & 17.85 & 1.64 \\
Hsp70-Grp75 & 17.16 & 1.90 \\
metabolism & & \\
enolase 3 & 14.51 & 5.28 \\
LDHB: lactate dehydrogenase chain B & 19.69 & 3.89 \\
MDH1: malate dehydrogenase 1 & 15.71 & 3.67 \\
oxidative resistance & & \\
DJ-1: Parkinson's disease protein 7 & 16.13 & 2.78 \\
Prdx6: cis-peroxiredoxin & 13.69 & 1.34 \\
SOD1: superoxide dismutase Cu/Zn & 16.26 & 1.36 \\
proteolysis & & \\
$\mu$-calpain & 16.50 & 1.99 \\
structure & & \\
CapZ- $\beta$ : F-actin-capping protein subunit $\beta$ & 15.90 & 2.33 \\
actin & 19.45 & 3.58 \\
MyBP-H: myosin binding protein H & 15.18 & 2.94 \\
MyLC-1F: myosin light chain 1F & 15.74 & 1.47 \\
MyHC-I: myosin heavy chain-I (\%) & 19.21 & 3.65 \\
MyHC-IIA: myosin heavy chain-IIa (\%) & 23.85 & 4.34 \\
MyHC-IIx/b: myosin heavy chain-IIx/b (\%) & 56.94 & 3.98 \\
\hline & & \\
\hline
\end{tabular}

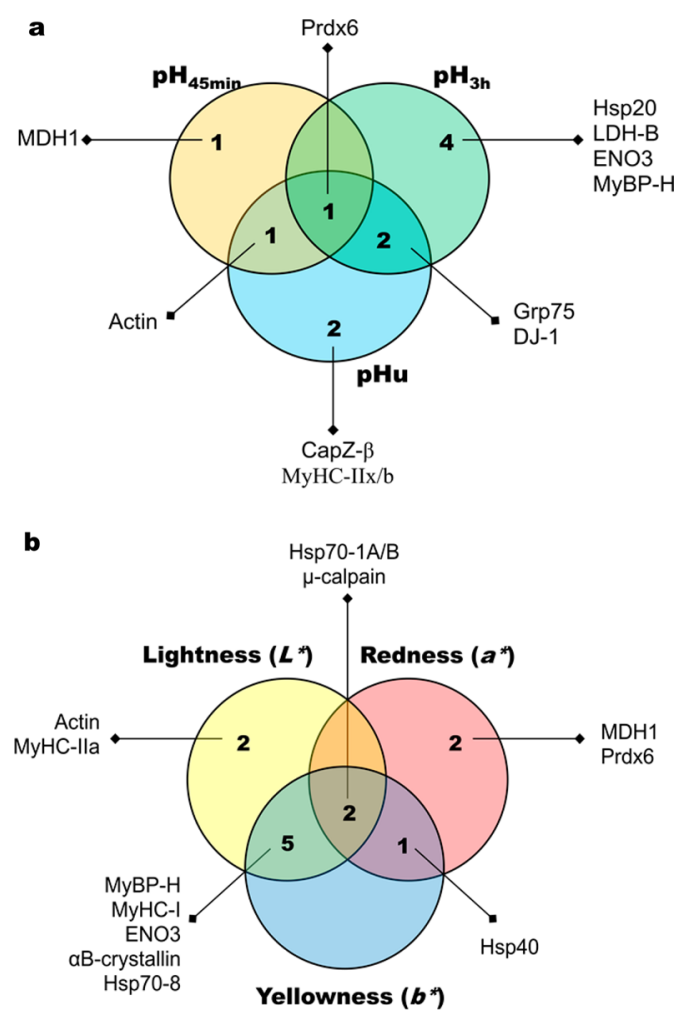

Figure 2. Venn diagrams depicting a summary of the number of biomarkers found significantly $(P<0.05)$ correlated with $(\mathrm{a}) \mathrm{pH}$ parameters and (b) color coordinates. The directions of the correlations are presented in PCAs (Figures 3 and 5).
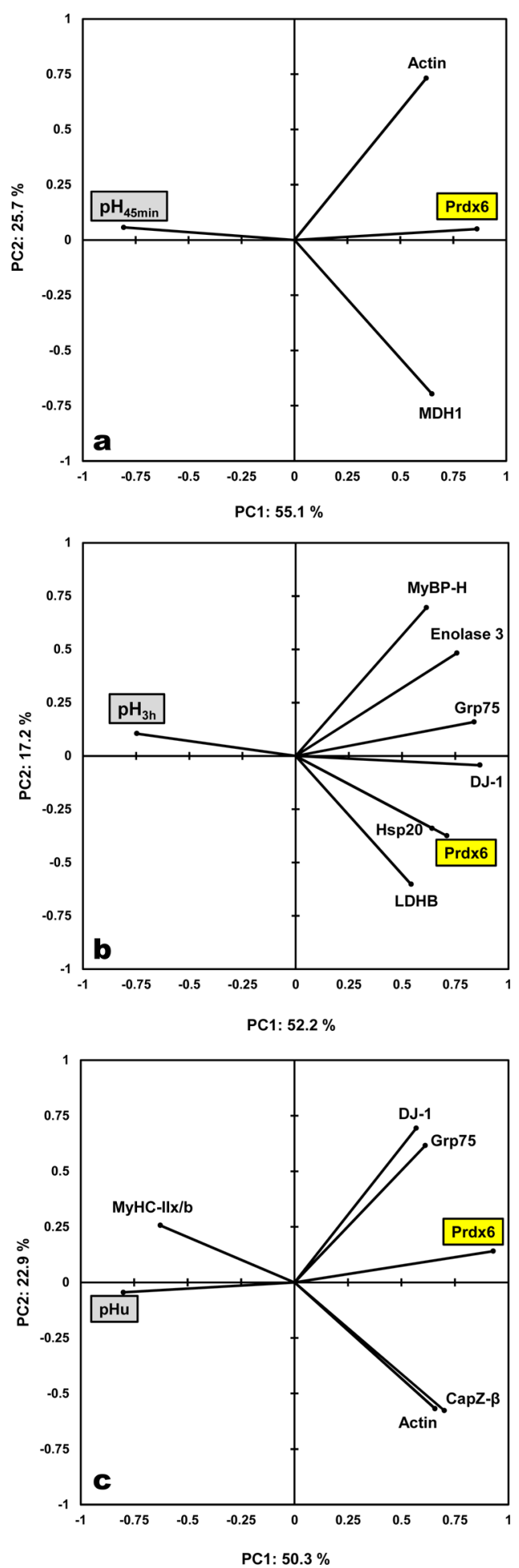

Figure 3. Principal component analyses showing relationships between (a) $\mathrm{pH}_{45 \text { min }}$ (b) $\mathrm{pH}_{3 \mathrm{~h}}$, and (c) $\mathrm{pH}_{\mathrm{u}}$ and the correlated biomarkers.

(negative) and Hsp70-8 (positive). For $\mathrm{pH}_{3 \mathrm{~h}}$, the model was almost similar to the $\mathrm{pH}_{45}$ min model and explained $59 \%$ of the variability $(P<0.001)$ in terms of LDH-B and actin (negative) and Hsp70-8 (positive). If included, Hsp27 (negative) was retained $(P<0.05)$ in the model, which then explains $67 \%$ of the variability. For ultimate $\mathrm{pH}$, it was not possible to construct a significant model with three variables. Hence, a fourth variable was included, producing a model explaining $58 \%$ of the variability 
Table 3. Regression Equations of $\mathrm{pH}_{45}$ min, $\mathrm{pH}_{3 \mathrm{~h}}$, and Ultimate $\mathrm{pH}$ of Longissimus thoracis Muscle of Blond d'Aquitaine Young Bulls Using Protein Biomarkers

\begin{tabular}{|c|c|c|c|c|c|c|c|}
\hline dependent variable & $\operatorname{adj}-R^{2 a}$ & SE & entered independent variable ${ }^{b}$ & partial $R^{2}$ & regression coefficient & $t$ value & $P$ value \\
\hline \multirow{3}{*}{$\mathrm{pH}_{45 \min }$} & $0.47 * *$ & 0.17 & MDH1 & 0.11 & -0.55 & -3.22 & 0.005 \\
\hline & & 0.20 & actin & 0.12 & -0.65 & -3.25 & 0.005 \\
\hline & & 0.20 & Hsp70-8 & 0.25 & +0.58 & +2.86 & 0.011 \\
\hline \multirow[t]{3}{*}{$\mathrm{pH}_{3 \mathrm{~h}}$} & $0.59 * * *$ & 0.15 & LDHB & 0.06 & -0.66 & -4.37 & 0.000 \\
\hline & & 0.18 & Hsp70-8 & 0.29 & +0.87 & +4.74 & 0.000 \\
\hline & & 0.17 & actin & 0.25 & -0.57 & -3.24 & 0.005 \\
\hline \multirow[t]{4}{*}{$\mathrm{pH}_{\mathrm{u}}$} & $0.58 * * *$ & 0.19 & Prdx6 & 0.31 & -0.69 & -3.72 & 0.002 \\
\hline & & 0.23 & Hsp70-1A/B & 0.08 & +0.68 & +3.00 & 0.008 \\
\hline & & 0.33 & Hsp40 & 0.04 & -0.86 & -2.58 & 0.020 \\
\hline & & 0.24 & MyLC-1F & 0.15 & +0.58 & +2.41 & 0.028 \\
\hline
\end{tabular}

${ }^{a}$ Significance of the models: $* *, P<0.01 ; * *, P<0.001 .{ }^{b}$ Variables are shown in order of their entrance in the prediction models.
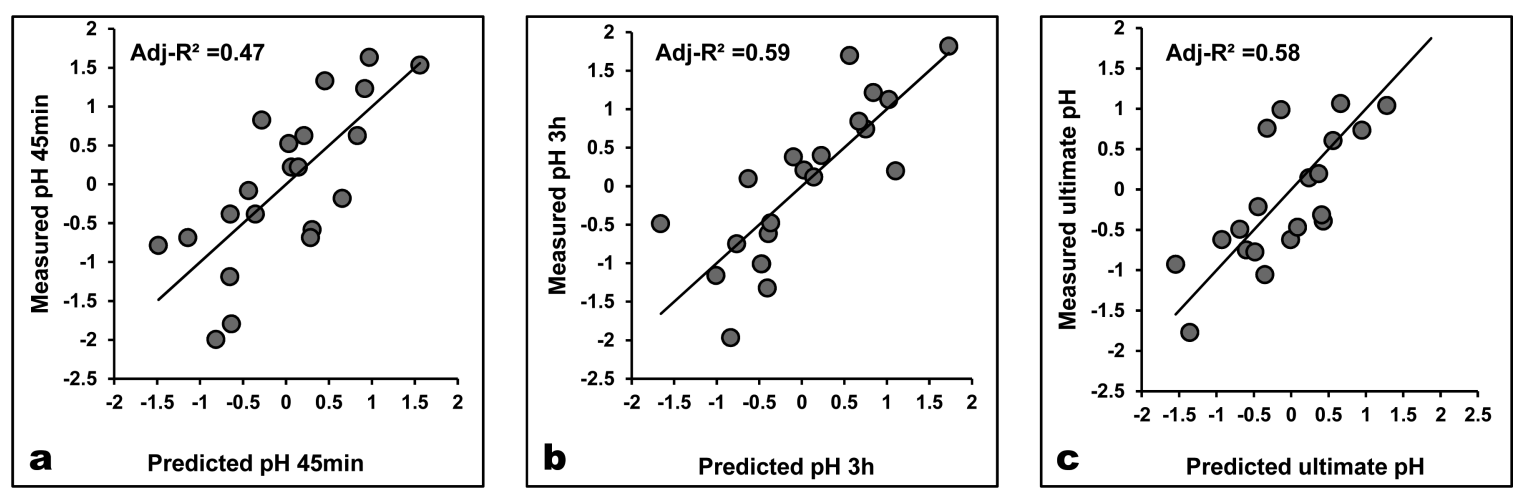

Figure 4. Correlations between measured and predicted $\mathrm{pH}_{45 \text { min }}, \mathrm{pH}_{3 \mathrm{~h}}$, and ultimate $\mathrm{pH}$ parameters using the best models. Adjusted $\mathrm{R}$-squares corresponding to the prediction equations given in Table 3 for each parameter are shown.

$(P<0.001)$ : Prdx6 and Hsp40 (negatively) and Hsp70-1A/B and MyLC-1F (positively).

Relationships between Biomarkers and Meat Color Traits. Pearson correlation analyses revealed that the three measured color parameters were not correlated $(r<0.29) . L^{*}$, $a^{*}$, and $b^{*}$ values were correlated with 12 biomarker abundances $(P<0.05$; in Figure 2b). Hsp70-1A/B and $\mu$-calpain were correlated with all color coordinates: negatively with $L^{*}$ and positively with $a^{*}$ and $b^{*}$ (Figures 5 and Figure 6). These two proteins were correlated together $(r=0.69, P<0.001)$. Five common correlations were found for $L^{*}$ and $b^{*}$, although directions differed. $L^{*}$ and $b^{*}$ were correlated with $\alpha \mathrm{B}$-crystallin $(r=$ -0.56 and $0.55, P<0.05$, respectively), Hsp70-8 $(r=-0.68$ and $0.41, P<0.05$; respectively), MyHC-I $(r=-0.53$ and 0.50 , $P<0.05$, respectively), ENO3 $(r=0.73$ and $-0.55, P<0.01$, respectively), and MyBP-H $(r=0.44$ and $-0.53, P<0.05$, respectively). Hsp40 was positively correlated with both $a^{*}$ and $b^{*}(r=0.65$ and $0.45, P<0.01$, respectively). Actin (negatively) and MyHC-IIa (positively) were correlated with $L^{*}$ only $(r=$ -0.51 and $0.46, P<0.05$, respectively). MDH1 and Prdx6 were positively correlated with $a^{*}$ only $(r=0.63$ and $0.46, P<0.01$, respectively). These two proteins were closely related $(r=0.50$, $P<0.05)$. PCAs were carried out for each color coordinate, introducing only the correlated biomarkers. The first two axes of the PCA explained $68.8,77.2$, and $75.5 \%$ of the variability between animals of $L^{*}$ (Figure 5a), $a^{*}$ (Figure $5 \mathrm{~b}$ ), and $b^{*}$ (Figure 5c), respectively.

Regression Models for Meat Color Traits. Simple correlations between $\mathrm{pH}$ values and color coordinates were not significant $(-0.34<r<0.10 ; p>0.13)$. The regression models using $L^{*} a^{*} b^{*}$ coordinates as dependent and $\mathrm{pH}$ and fiber types as independent variables found a significant model only for $L^{*}$, explaining $37.9 \%$ of the variability with $\mathrm{pH}_{\mathrm{u}}(13.5 \%$; $P<0.05)$ and MyHC-I $(24.4 \% ; P<0.01): L^{*}=-0.4^{*} \mathrm{pH}_{\mathrm{u}}-$ $0.7^{*}$ MyHC-I. The regression models using $L^{*} a^{*} b^{*}$ color traits as dependent and biomarker abundances as independent variables are presented in Table 4 and Figure 7 . The models were significant and explained between 47 and $65 \%$ of variability. The model of $L^{*}$ explained $65 \%$ of the variability between animals $(P<0.0001)$ by ENO3 (positive) and Hsp70-Grp75 (negative). The model of $a^{*}$ explained $62 \%$ of the variability $(P<0.001)$ by Hsp40 (positive) and SOD1 and Hsp70-8 (both negative). The model of $b^{*}$ explained $47 \%$ of the variability $(P<0.01)$ by $\mu$-calpain (positive) and Hsp70-Grp75 (negative). Both $L^{*}$ and $b^{*}$ models included Hsp70-Grp75, explaining 17 and $24 \%$, respectively. All of the $L^{*} a^{*} b^{*}$ color coordinate models included heat shock proteins, which explained between 17 and $50 \%$ of the variability.

\section{DISCUSSION}

Results indicate that $L^{*}, a^{*}$, and $b^{*}$ color coordinates were unrelated among themselves and that only $L^{*}$ was weakly correlated with ultimate $\mathrm{pH}$. Earlier studies on pork and cattle found correlations between ultimate $\mathrm{pH}, L^{*}$, and $b^{*}{ }^{4}$ The absence of strong correlations with ultimate $\mathrm{pH}$ in the present study can be explained by the fact that ultimate $\mathrm{pH}$ values were within the normal range. ${ }^{5}$ Redness $\left(a^{*}\right)$ is generally more influenced by early post-mortem $\mathrm{pH}$. Particularly, at least in 

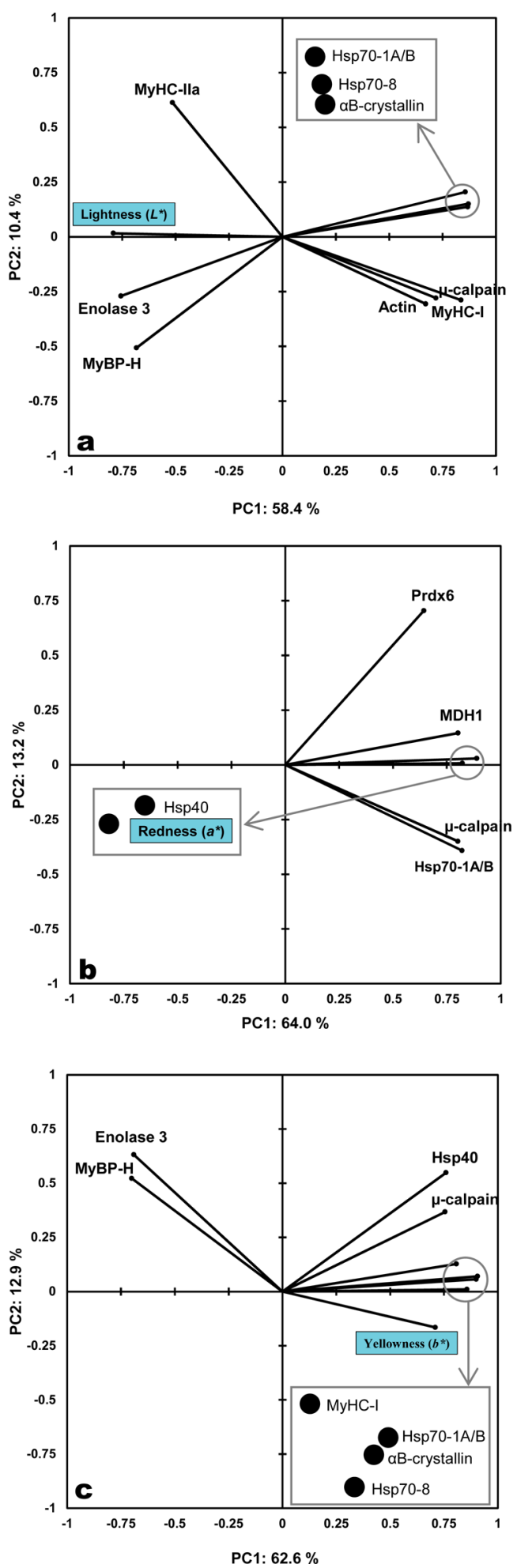

Figure 5. Principal component analyses showing relationships between (a) lightness $\left(L^{*}\right),(\mathrm{b})$ redness $\left(a^{*}\right)$, and $(\mathrm{c})$ yellowness $\left(b^{*}\right)$ and the correlated biomarkers.

pork, the combination of low early post-mortem thigh muscle temperature results in protein denaturation that leads to early inactivation of oxygen-consuming enzymes. ${ }^{5}$ This promotes formation of $\mathrm{MbO}_{2}$, leading to higher $a^{*}$ values. ${ }^{25}$ The absence of a correlation in the present study may be due to the use of cattle rather than pigs and/or the narrow range of early postmortem $\mathrm{pH}$ values, compared to the study by Lindahl et al. ${ }^{5}$

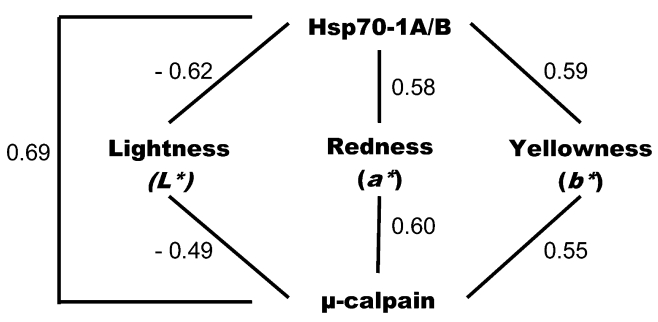

Figure 6. Pearson correlation analysis showing significant correlations $(P<0.05)$ between $L^{*} a^{*} b^{*}$ color coordinates and both Hsp70-1A/B and $\mu$-calpain.

To increase our understanding of the biochemical mechanisms underlying post-mortem $\mathrm{pH}$ decline and color development in young Blond d'Aquitaine bulls, the following sections will discuss the relationships between these variables and the proteins (biomarkers) measured in the present study using the Dot-Bot technique.

Relationship between Biomarkers in the Early PostMortem Period and Post-Mortem pH Decline. $\mathrm{pH}_{45 \mathrm{~min}}$. $\mathrm{PCA}$ and regression analyses show that $\mathrm{pH}_{45}$ min was correlated with four proteins (Actin, MDH1, Prdx6, and Hsp70-8), all implicated in apoptosis. Apoptosis is considered to start a few minutes after bleeding and to play a major role in the conversion of muscle to meat. ${ }^{12,26}$ Apoptosis is initiated due to the hypoxic state of the muscle cells resulting in changes in the inner mitochondrial cell membrane that cause the release of pro-apoptotic proteins into the cytoplasm. ${ }^{26}$ These events activate the caspase cascade, which is central in the apoptotic process. Actin is the first protein targeted by caspases. Actin fragments can induce morphological changes resembling apoptotic cells and may be used as a probe for apoptosis detection. ${ }^{12,27}$ In coherence with our findings, proteomic studies found that in the early post-mortem period, actin fragments are released and that $\mathrm{pH}$ decline and actin degradation were closely related. ${ }^{12,28,29}$

In the early post-mortem period, as long as glycolytic enzymes are not inhibited by low $\mathrm{pH}$, glycolysis will continue, thus contributing to the acidification process. MDH1 plays a pivotal role in the malate-aspartate shuttle operating between cytosol and mitochondria, which may explain the correlation between $\mathrm{MDH} 1$ and $\mathrm{pH}_{45}$ min. ${ }^{30} \mathrm{MDH} 1$ may also be implicated in apoptosis, as in response to glucose deprivation, $\mathrm{MDH} 1$ regulates p53-dependent cell-cycle arrest and apoptosis. ${ }^{31}$

In our study, low $\mathrm{pH}_{45}$ min was also associated with higher Prdx6, a bifunctional protein with both glutathione peroxidase (GPx, antioxidative) and phospholipase A2 $\left(\mathrm{PLA}_{2}\right)$ activities. $^{32}$ The relationship between Prdx6 and $\mathrm{pH}$ decline may be partly explained by the activity of the $\mathrm{PLA}_{2}$ group. This group plays a significant role in the hydrolysis of phosphatidylcholine (PC), which is a basic phospholipid present in cell membranes. ${ }^{33}$ Phosphatidylserine (PS) is the acid phospholipid present in cell membranes. At the early stages of apoptosis, the phospholipid distribution in the cell membranes is inverted: PS switches to the external and PC to the internal leaflet of the membrane by a flip-flop process. ${ }^{26,34}$ Due to this inversion, protons generated by glycolysis may be partly absorbed and the acidification process may be slowed. Due to $\mathrm{PLA}_{2}$ activity, PC will be hydrolyzed, reducing its buffering capacity and thus enhancing the rate of $\mathrm{pH}$ decline in the cytosol.

Hsp70-8, a member of the Hsp70 kDa family, was positively related to early post-mortem $\mathrm{pH}$. This Hsp is constitutively expressed in most tissues and essential for survival. It has many 
Table 4. Regression Equations of $L^{*} a^{*} b^{*}$ Meat Color Traits of Longissimus thoracis Muscle of Blond d'Aquitaine Young Bulls Using Protein Biomarkers

\begin{tabular}{|c|c|c|c|c|c|c|c|}
\hline dependent variable & $\operatorname{adj}-R^{2 a}$ & SE & entered independent variable ${ }^{b}$ & partial $R^{2}$ & regression coefficient & $t$ value & $P$ value \\
\hline \multirow[t]{2}{*}{ lightness $\left(L^{*}\right)$} & $0.65 * * *$ & 0.17 & ENO 3 & 0.48 & +1.05 & +6.14 & 0.0001 \\
\hline & & 0.17 & Hsp70-Grp75 & 0.17 & -0.51 & -2.99 & 0.008 \\
\hline \multirow[t]{3}{*}{ redness $\left(a^{*}\right)$} & $0.62 * * *$ & 0.22 & Hsp40 & 0.33 & +1.22 & +5.60 & 0.0001 \\
\hline & & 0.17 & SOD1 & 0.12 & -0.56 & -3.38 & 0.004 \\
\hline & & 0.20 & Hsp 70-8 & 0.17 & -0.57 & -2.78 & 0.013 \\
\hline \multirow[t]{2}{*}{ yellowness $(b *)$} & $0.47^{* *}$ & 0.17 & $\mu$-calpain & 0.23 & +0.64 & +3.86 & 0.001 \\
\hline & & 0.17 & Hsp70-Grp75 & 0.24 & -0.48 & -2.92 & 0.009 \\
\hline
\end{tabular}

${ }^{a}$ Significance of the models: $* *, P<0.01$; $* * *, P<0.001{ }^{b}$ Variables are shown in order of their entrance in the prediction models.
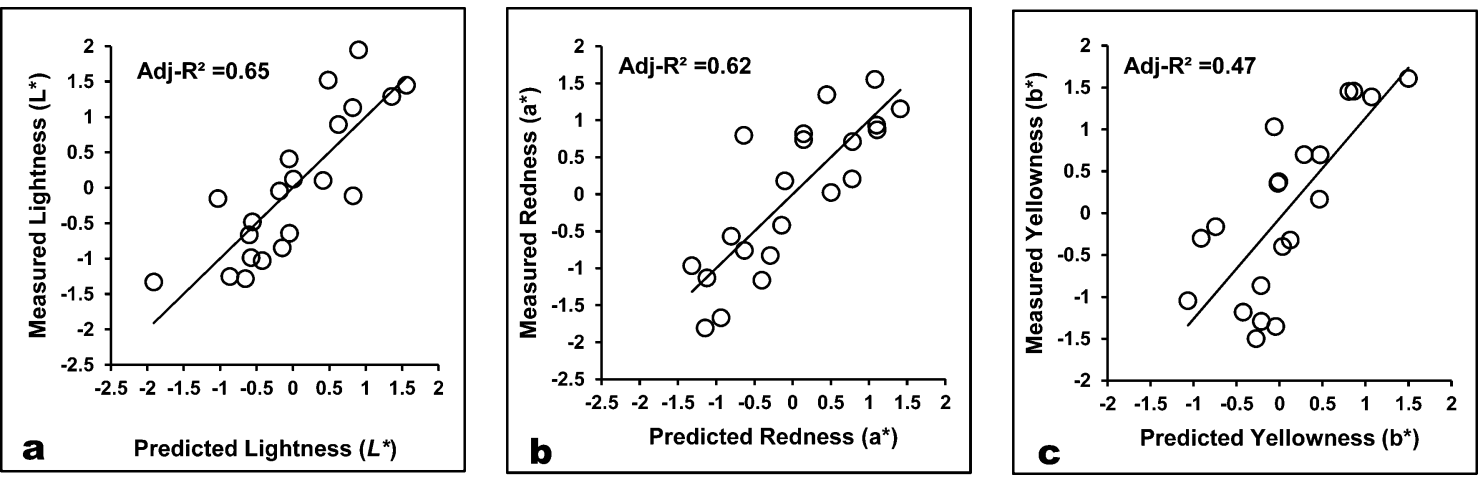

Figure 7. Correlations between predicted and measured (a) lightness $\left(L^{*}\right),(\mathrm{b})$ redness $\left(a^{*}\right)$, and (c) yellowness $\left(b^{*}\right)$ color traits using the best models. Adjusted $R$-squares corresponding to the prediction equations given in Table 4 for each parameter are shown.

housekeeping chaperoning functions including folding of nascent polypeptides, protein translocation across membranes, chaperonemediated autophagy, and prevention of protein aggregation under stress conditions. ${ }^{35}$ Due to its protective functions, increased metabolic activity may have led to increased levels and vice versa, explaining its relationship with early post-mortem $\mathrm{pH}$.

$\mathrm{pH}_{3 h}$. PCA and regression analyses show that $3 \mathrm{~h}$ postmortem, the biological pathways appear partly similar to those involved in $\mathrm{pH}_{45 \mathrm{~min}}$. Several other proteins are also involved, and these new relationships become apparent due to the greater time span during which protons have been able to accumulate. The correlated proteins are implicated in glycolysis (ENO3 and LDH-B), heat stress (Hsp20, Hsp70-Grp75, and Hsp70-8), oxidative resistance (Prdx6 and DJ-1), and structure (actin and MyBP-H). Results show that high levels of these biomarkers $45 \mathrm{~min}$ post-mortem predict low $\mathrm{pH}$ about $2 \mathrm{~h}$ later. ENO3 and $\mathrm{LDH}-\mathrm{B}$ are glycolytic enzymes, and their negative association with $\mathrm{pH}_{3 \mathrm{~h}}$ is undoubtedly explained by a faster energy metabolism resulting in a faster $\mathrm{pH}$ decline.

High levels of MyBP-H proteins at $45 \mathrm{~min}$ post-mortem predicted also low $\mathrm{pH}_{3 \text { h }}$ post-mortem. MyBP-H is a cytoskeletal protein interacting with myosin thick filaments in the A-band. ${ }^{36}$ Its relationship with $\mathrm{pH}_{3 \mathrm{~h}}$ may have been indirect as higher MyBP-H levels were associated with higher levels of ENO3 and LDH-B. The Dot-Blot protocol used in the present study allowed revealing both intact and fragmented protein molecules in the soluble fraction. Higher MyBP-H levels in the early postmortem period would suggest a faster fragmentation of these structural proteins, which may result from a faster early postmortem metabolism.

Higher Hsp20 levels may occur in response to metabolic activity and $\mathrm{pH}$ decline, to stabilize myofibrillar proteins. ${ }^{37}$ For example,
Lomiwes et al. ${ }^{38}$ demonstrated that a slight decrease in postmortem muscle $\mathrm{pH}$ induces a rapid binding of another small Hsp of the same family, $\alpha \mathrm{B}$-crystallin, to the myofibril. Higher Hsp20 levels $45 \mathrm{~min}$ post-mortem may thus have been indicative of a faster metabolism and consequently be predictive of lower $\mathrm{pH}_{3 \mathrm{~h}}$.

Hsp70-Grp75 was related to $\mathrm{pH}_{3 \mathrm{~h}}, \mathrm{pH}_{\mathrm{w}}$ and $L^{*}$ and $b^{*}$ color coordinates. Hsp70-Grp75 is a cytoprotective chaperone present in nearly all cellular compartments and induced by glucose deprivation, $\mathrm{Ca}^{2+}$ influx, or agents perturbing glycolysis. ${ }^{39}$ It assists in the import and folding of mitochondrial proteins and protects cells from glucose deprivation and ROS accumulation. ${ }^{40}$ Its protective function may explain the relationship between its higher levels at $45 \mathrm{~min}$ post-mortem and the subsequent faster $\mathrm{pH}$ decline. Hsp70-Grp75 sequesters and inactivates p53, preventing its nuclear translocation and apoptosis. ${ }^{41}$ Hsp70-Grp75 may thus slow apoptotic and other processes involved in the conversion of muscle to meat. In addition, Hsp70-Grp75 links the inositol 1,4,5-trisphosphate receptor of the endoplasmic reticulum to the mitochondrial voltage-dependent anion channels, presumably enhancing $\mathrm{Ca}^{2+}$ trafficking from the endoplasmic reticulum toward the mitochondria. ${ }^{12}$ This mechanism may also contribute to the relationship between Hsp70-Grp75 and $\mathrm{pH}$ decline as $\mathrm{Ca}^{2+}$ exerts regulatory effects on many enzymes and proteins involved in metabolic and apoptotic processes including in the postmortem muscle. ${ }^{12,42}$

The different functions of Prdx6 have been discussed above. Hence, increased Prdx6 levels 45 min post-mortem predicted low $\mathrm{pH} 3 \mathrm{~h}$ post-mortem probably partly due to its $\mathrm{PLA}_{2}$ activity on $\mathrm{pH}$ decline. In addition, $3 \mathrm{~h}$ post-mortem $\mathrm{pH}$ was around 6.2 and less unfavorable for the activity of the GPx group of Prdx6. ${ }^{32}$ Thus, approaching $3 \mathrm{~h}$ post-mortem, Prdx6 may have acted as an antioxidant, thereby protecting metabolic activity. 
DJ-1 is another antioxidant protein present in the cytoplasm as well as in intracellular organelles and scavenges $\mathrm{H}_{2} \mathrm{O}_{2}$ through oxidation of Cys-106. ${ }^{43} \mathrm{DJ}-1$ is further believed to promote the expression of a number of mitochondrial enzymes involved in reactive oxygen species (ROS) removal. ${ }^{44}$ Its association with increased levels of glycolytic enzymes and Prdx6 is coherent with its association with a faster early post-mortem $\mathrm{pH}$ decline.

Ultimate $\mathrm{pH}$. Ultimate $\mathrm{pH}$ was earlier found to be correlated with levels of various muscle proteins present in beef and pork muscles 45 min post-mortem. ${ }^{11}$ In the present study, high levels of structural proteins (actin, CapZ- $\beta$, MyLC- $1 \mathrm{~F}$, and MyHC-IIx/b), chaperones (Hsp70-Grp75, Hsp70-1A/B, and Hsp40), and oxidative resistance (DJ-1 and $\operatorname{Prdx} 6$ ) proteins $45 \mathrm{~min}$ post-mortem predicted low $\mathrm{pH}_{\mathrm{u}}$. In contrast to $\mathrm{pH}_{45 \text { min }}$ and $\mathrm{pH}_{3 \mathrm{~h}}$, low $\mathrm{pH}_{\mathrm{u}}$ was not predicted by high levels of glycolytic enzymes, although $\mathrm{pH}$ values at different post-mortem intervals were correlated. This is coherent with the knowledge that the glycolytic rate is not the sole determining factor for $\mathrm{pH}_{\mathrm{u}}$. The extent of $\mathrm{pH}$ decline may be reduced if glycogen reserves are limiting. In the present experiment, preslaughter stress levels were low and glycogen levels were not the limiting factor as we have recently showed that $24 \mathrm{~h}$ post-mortem the muscles of the same BA bulls contained residual glycogen.$^{21}$ If glycogen content is not the limiting factor, glycolysis stops due to other factors, probably related to the disappearance of AMP and the inactivation of glycolytic enzymes. ${ }^{45}$

High actin and CapZ- $\beta$ contents 45 min post-mortem predicted low $\mathrm{pH}_{\mathrm{u}}$. CapZ- $\beta$ is located in the $\mathrm{Z}$ band of the muscle sarcomere and caps the barbed (plus) end of actin filaments, inhibiting polymerization. ${ }^{46} \mathrm{~A}$ proteomic study found that CapZ- $\beta$ was retained in the insoluble fraction of the protein extraction and that levels declined during the $48 \mathrm{~h}$ following slaughter, ${ }^{10}$ indicative of progressive CapZ- $\beta$ fragmentation or detachment from the $\mathrm{Z}$ band. As for MyBP-H (cf. above), the higher levels of actin and CapZ- $\beta$ in the early post-mortem period would suggest a relatively fast fragmentation of these structural proteins. The association between faster structural protein degradation and higher levels of protective proteins (Prdx6, DJ-1, Hsp70-Grp75) 45 min post-mortem may thus express a faster metabolism. The association between higher levels of protective proteins and lower $\mathrm{pH}_{\mathrm{u}}$ suggests that these pathways effectively protected the cell against adverse events such as oxidative stress, presumably retarding apoptosis and preserving energy metabolism. The association between high $\mathrm{MyHC}-\mathrm{IIx} / \mathrm{b}$ content and high ultimate $\mathrm{pH}$ may seem unexpected. A higher MyHC-IIx/b content is usually associated with higher glycogen content and a potential for a faster metabolism, which, depending on the slaughter conditions, may result in a lower, rather than a higher, $\mathrm{pH}_{\mathrm{u}}{ }^{3}$

Meat Color Traits. Mean $L^{*}$ values of the meat samples of the BA breed were within the range of normal values. ${ }^{47}$ The redness $\left(a^{*}\right)$ values were lower and yellowness $\left(b^{*}\right)$ values were higher than those reported in the literature. ${ }^{48}$ This may be partly due to the relatively high content of glycolytic fibers of the LT muscle of the BA breed. ${ }^{20}$ These fibers contain less myoglobin, resulting in lower redness, and are less efficient in oxygen exchange compared to oxidative fibers, resulting in a less reductive environment and thus promoting $\mathrm{MbO}_{2}$ formation with a net result of greater yellowness. $^{25}$

Relationships between Biomarkers and Meat Color Traits. PCA and regression analyses showed that $L^{*}, a^{*}$, and $b^{*}$ values were correlated with 10,7 , and 10 biomarker abundances, respectively. $L^{*}$ and $b^{*}$ showed seven correlations with the same proteins but in the opposite direction. The present study used proteins related to various beef sensory qualities including tenderness. ${ }^{14}$ Although proteomic studies on pork, beef, and fish found relationships between color and proteins involved in muscle contraction, metabolism, heat stress, signaling, and other functions, ${ }^{16-19}$ little information exists on the relationships between beef color and biomarkers validated for other meat qualities. $^{49}$

In the present study, $\mu$-calpain and $H$ sp70-1A/B were correlated with the three color coordinates. Similarly, Joseph et al. ${ }^{18}$ identified three overabundant chaperone proteins that were related to beef meat color stability, including a Hsp-1B of $70 \mathrm{kDa}$. Kwasiborski et al. ${ }^{11}$ found a negative correlation between abundance of an Hsp70 isoform (Hsp72 or Hsp70-1A/B) 45 min postmortem and $L^{*}$ in pig LT muscles. Hsp70-1A/B is a member of the inducible Hsp70 family and is abundantly induced in response to cellular stress, possibly due to its function to preserve proteins. ${ }^{40}$ One hypothesis is that inducible Hsp70s and $\mu$-calpain influence certain meat color coordinates interactively. First, post-mortem ROS damage of the endoplasmic reticulum of the cells leads to the liberation of $\mathrm{Ca}^{2+}$ in the cytosol, which activates $\mu$-calpain. Structural proteins are a major substrate of $\mu$-calpain, and their characteristics influence meat color aspects. Second, inducible Hsp70s may interfere in this process. Post-mortem, oxidative stress induced by a product of lipid peroxidation, 4-hydroxy-2-nonenal (4-HNE), an $\alpha, \beta$-unsaturated aldehyde, ${ }^{8}$ causes carbonylation of $\mathrm{Hsp} 70,{ }^{50}$ thus inactivating it. It was recently reported that in monkey hippocampal CA1 neurons, carbonylated Hsp70s are key substrates of $\mu$-calpain. ${ }^{51}$ If this pathway exists also in muscle, the carbonylated forms of inducible Hsp70 may be hydrolyzed by $\mu$-calpain. ${ }^{51} 4$-HNE may also contribute to the phenomenon as it may cause disruption of $\mathrm{Ca}^{2+}$ homeostasis, membrane and structure damage, and cell death. ${ }^{52}$ In support of this hypothesis, 4-HNE was reported to affect meat color by formation of several adducts with muscle proteins, thus modifying protein functionality. ${ }^{53,54}$ Thus, increased levels of carbonylated Hsp70s will protect structural proteins against $\mu$-calpain activity, thereby deferring changes in the structure of pigment and myofibrillar proteins, influencing hence reflectance and other aspects of meat color. Inducible $\mathrm{Hsp} 70$ binds also with membrane phospholipids ${ }^{55}$ and interacts with PLA2 activity ${ }^{56}$ and may thus participate in reactions involving phospholipids, $\mathrm{pH}$ decline, and apoptosis onset.

Other Hsps were also correlated with color coordinates. Hsp70-8 and $\alpha \mathrm{B}$-crystallin were negatively and positively correlated with $L^{*}$ and $b^{*}$, respectively. Hsp40 was positively correlated with $a^{*}$. Other studies found also relationships between Hsp contents of the early post-mortem muscle and color coordinates. Zhang et al. ${ }^{57}$ reported opposite relationships between Hsp90 contents in the early post-mortem muscle and $L^{*}$ and $b^{*}$ in pigs. The involvement of Hsps in meat color may be in part related to their protective role against protein denaturation known to affect the reflectance of meat aspects. ${ }^{19}$ Overall, these relationships indicate that inducible and constitutively expressed Hsps may play a major role in the determination of meat color.

The association between slow twitch oxidative fibers (type I) and $L^{*}$ and $b^{*}$ coordinates may be related to their relatively high content of myoglobin, which explains part of the variation in meat color. ${ }^{25}$ In addition, they contain high levels of inducible Hsp70, of which the potential role has been described above.

The positive correlation between redness $\left(a^{*}\right)$ and $\operatorname{Prdx} 6$ can be explained by the involvement of the GPx group, which has antioxidative properties. Tang et al. ${ }^{58}$ reported that adding glutathione to bovine muscle cytosol improved $\mathrm{MbO}_{2}$ redox stability, allowing increased redness. The present study found 
also a positive correlation between $\mathrm{MDH} 1$ and $a^{*}$ values. Glycolytic enzymes were earlier found to be positively correlated with redness $\left(a^{*}\right)$ in beef. ${ }^{16,18}$ In the presence of a reductor, MetMb can be converted back into $\mathrm{Mb}$. The reduction process is primarily enzymatic in nature with $\mathrm{NADH}$ as cofactor and can take place under anaerobic or aerobic conditions. ${ }^{1}$ The glycolytic pathway allows the production of $\mathrm{NADH},{ }^{1,59}$ which may explain the correlation between $a^{*}$ and MDH1.

While many studies have shown relationships between beef color and protein biomarkers after $\geq 24 \mathrm{~h}$ post-mortem, the present study shows that protein biomarkers present in the early post-mortem period may predict subsequent $\mathrm{pH}$ decline and color development. Overall, the results show that correlations between $\mathrm{pH}$ decline, meat color coordinates, and protein biomarkers reflect existing knowledge on post-mortem muscle processes involved in $\mathrm{pH}$ decline and meat color determinism. The role of the distribution of muscle fibers is probably due to their myoglobin content, directly influencing color, and mitochondria content, involved in the initiation of the apoptosis process. The involvement of Hsps and oxidative proteins is explained by their protective functions, thereby preserving metabolism and retarding proteolysis and apoptosis onset. Antioxidants maintain further the redox state, thus stabilizing myoglobin. Prdx6 plays an important role, probably due to its dual functions of antioxidant and phospholipase activities. Enzymes of the glycolytic pathways influence $\mathrm{pH}$ decline and thus, indirectly, color stability, but deliver also energy and cofactors $(\mathrm{NADH})$ allowing reduction of MetMb. The degree of fragmentation of structural proteins reveals the proteolytic and apoptotic status of the cell, and being substrates that may also enhance these processes. $\mathrm{pH}$ plays an important role as it influences the activity of at least part of the proteins (e.g., sHsps and Prdx6).

Thus, several of the tested biomarkers have been identified as being relevant for the traits of interest, and their relationships with the traits have been discussed in terms of possible underlying biochemical mechanisms. Before these biomarkers can be used as an industrial tool, further developments are needed. For example, the robustness of the relationship, in terms of breed, gender, feeding regimen, and muscle, should be investigated. The knowledge presented here should allow a greater understanding of similarities but also of differences that may exist with other animal types than the one studied. In addition, techniques for routine measurements must be developed (for example, DotBlot or antibody microarray techniques ${ }^{13,60}$ ). Once developed, the meat industry may benefit from the use of biomarkers as a tool for investigation, monitoring, or decision/management. In addition, knowledge of the biochemical pathways involved in meat color development and stability may be used to control or improve meat aspects under field conditions. As indicated above, addition of pyruvate to beef cuts improved meat color, as pyruvate regenerates $\mathrm{NADH}$ through the TCA cycle, leading to MetMb reduction. ${ }^{8}$ Similar results were obtained for the addition of $\mathrm{NAD}^{+}$, lactate, or $\mathrm{LDH}$.

\section{AUTHOR INFORMATION}

\section{Corresponding Author}

*(B.P.) Phone: 334736240 56. Fax: 334736246 39. E-mail: brigitte.picard@clermont.inra.fr.

\section{Funding}

This work was part of the EU FP6 Integrated Project ProSafeBeef, Contract FOODCT-2006-36241 (INRA Quality Assurance AQ284). Funding by the European Union is gratefully acknowledged with respect to animal production and laboratory analyses. We are further thankful to the Franco-Algerian PROFAS $\mathrm{B}+$ program for the financial support given to M.G. (Ph.D.).

\section{Notes}

The authors declare no competing financial interest.

\section{ACKNOWLEDGMENTS}

We thank INRA UERT (Theix) for animal management and slaughter.

\section{REFERENCES}

(1) Mancini, R. A.; Hunt, M. C. Current research in meat color. Meat Sci. 2005, 71, 100-121.

(2) Mancini, R. A. 4 - Meat color. In Improving the Sensory and Nutritional Quality of Fresh Meat; Kerry, J. P., Ledward, D., Eds.; Woodhead Publishing: Cambridge, UK, 2009; pp 89-110.

(3) Renerre, M.; Anton, M.; Gatellier, P. Autoxidation of purified myoglobin from two bovine muscles. Meat Sci. 1992, 32, 331-342.

(4) Abril, M.; Campo, M. M.; Önenç, A.; Sañudo, C.; Albertí, P.; Negueruela, A. I. Beef colour evolution as a function of ultimate $\mathrm{pH}$. Meat Sci. 2001, 58, 69-78.

(5) Lindahl, G.; Henckel, P.; Karlsson, A. H.; Andersen, H. J. Significance of early postmortem temperature and $\mathrm{pH}$ decline on colour characteristics of pork loin from different crossbreeds. Meat Sci. 2006, 72, 613-623.

(6) Boudjellal, A.; Becila, S.; Coulis, G.; Herrera-Mendez, C. H.; Aubry, L.; Lepetit, J.; Harhoura, K.; Sentandreu, M. A.; Ait-Amar, H.; Ouali, A. Is the $\mathrm{pH}$ drop profile curvilinear and either monophasic or polyphasic? Consequences on the ultimate bovine meat texture. Afr. J. Agric. Res. 2008, 3, 195-204.

(7) Suman, S. P.; Joseph, P. Myoglobin chemistry and meat color. Annu. Rev. Food Sci. Technol. 2013, 4, 79-99.

(8) Joseph, P.; Nair, M. N.; Suman, S. P. Application of proteomics to characterize and improve color and oxidative stability of muscle foods. Food Res. Int. 2015, DOI: 10.1016/j.foodres.2015.05.041.

(9) Faustman, C.; Liebler, D. C.; McClure, T. D.; Sun, Q. $\alpha, \beta$ Unsaturated aldehydes accelerate oxymyoglobin oxidation. J. Agric. Food Chem. 1999, 47, 3140-3144.

(10) Bjarnadottir, S. G.; Hollung, K.; Faergestad, E. M.; Veiseth-Kent, E. Proteome changes in bovine longissimus thoracis muscle during the first $48 \mathrm{~h}$ postmortem: shifts in energy status and myofibrillar stability. J. Agric. Food Chem. 2010, 58, 7408-7414.

(11) Kwasiborski, A.; Sayd, T.; Chambon, C.; Sante-Lhoutellier, V.; Rocha, D.; Terlouw, C. Pig Longissimus lumborum proteome: Part II: Relationships between protein content and meat quality. Meat Sci. 2008, 80, 982-996.

(12) Ouali, A.; Gagaoua, M.; Boudida, Y.; Becila, S.; Boudjellal, A.; Herrera-Mendez, C. H.; Sentandreu, M. A. Biomarkers of meat tenderness: present knowledge and perspectives in regards to our current understanding of the mechanisms involved. Meat Sci. 2013, 95, 854-870.

(13) Picard, B.; Lebret, B.; Cassar-Malek, I.; Liaubet, L.; Berri, C.; Le Bihan-Duval, E.; Hocquette, J. F.; Renand, G. Recent advances in omic technologies for meat quality management. Meat Sci. 2015, DOI: $10.1016 /$ j.meatsci.2015.05.003.

(14) Picard, B.; Gagaoua, M.; Micol, D.; Cassar-Malek, I.; Hocquette, J. F.; Terlouw, C. E. Inverse relationships between biomarkers and beef tenderness according to contractile and metabolic properties of the muscle. J. Agric. Food Chem. 2014, 62, 9808-9818.

(15) Guillemin, N.; Meunier, B.; Jurie, C.; Cassar-Malek, I.; Hocquette, J. F.; Leveziel, H.; Picard, B. Validation of a Dot-Blot quantitative technique for large scale analysis of beef tenderness biomarkers. J. Physiol. Pharmacol. 2009, 60 (Suppl. 3), 91-97.

(16) Canto, A. C.; Suman, S. P.; Nair, M. N.; Li, S.; Rentfrow, G.; Beach, C. M.; Silva, T. J.; Wheeler, T. L.; Shackelford, S. D.; Grayson, A.; McKeith, R. O.; King, D. A. Differential abundance of sarcoplasmic proteome explains animal effect on beef Longissimus lumborum color stability. Meat Sci. 2015, 102, 90-98. 
(17) Desai, M. A.; Joseph, P.; Suman, S. P.; Silva, J. L.; Kim, T.; Schilling, M. W. Proteome basis of red color defect in channel catfish (Ictalurus punctatus) fillets. LWT - Food Sci. Techno. 2014, 57, 141148.

(18) Joseph, P.; Suman, S. P.; Rentfrow, G.; Li, S.; Beach, C. M. Proteomics of muscle-specific beef color stability. J. Agric. Food Chem. 2012, 60, 3196-3203.

(19) Sayd, T.; Morzel, M.; Chambon, C.; Franck, M.; Figwer, P.; Larzul, C.; Le Roy, P.; Monin, G.; Cherel, P.; Laville, E. Proteome analysis of the sarcoplasmic fraction of pig semimembranosus muscle: implications on meat color development. J. Agric. Food Chem. 2006, 54, 2732-2737.

(20) Listrat, A.; Picard, B.; Jailler, R.; Collignon, H.; Peccatte, J.-R.; Micol, D.; Geay, Y.; Dozias, D. Grass valorisation and muscular characteristics of blonde d'Aquitaine steers. Ann. Zootech. 2001, 50, 105-118.

(21) Bourguet, C.; Deiss, V.; Boissy, A.; Terlouw, E. M. C. Young Blond d'Aquitaine, Angus and Limousin bulls differ in emotional reactivity: relationships with animal traits, stress reactions at slaughter and post-mortem muscle metabolism. Appl. Anim. Behav. Sci. 2015, $164,41-55$.

(22) Bouley, J.; Chambon, C.; Picard, B. Mapping of bovine skeletal muscle proteins using two-dimensional gel electrophoresis and mass spectrometry. Proteomics 2004, 4, 1811-1824.

(23) Bradford, M. M. A rapid and sensitive method for the quantitation of microgram quantities of protein utilizing the principle of protein-dye binding. Anal. Biochem. 1976, 72, 248-254.

(24) Picard, B.; Barboiron, C.; Chadeyron, D.; Jurie, C. Protocol for high-resolution electrophoresis separation of myosin heavy chain isoforms in bovine skeletal muscle. Electrophoresis 2011, 32, 18041806.

(25) Lindahl, G.; Lundstrom, K.; Tornberg, E. Contribution of pigment content, myoglobin forms and internal reflectance to the colour of pork loin and ham from pure breed pigs. Meat Sci. 2001, 59, 141-151.

(26) Ouali, A.; Herrera-Mendez, C. H.; Coulis, G.; Becila, S.; Boudjellal, A.; Aubry, L.; Sentandreu, M. A. Revisiting the conversion of muscle into meat and the underlying mechanisms. Meat Sci. 2006, $74,44-58$.

(27) Mashima, T.; Naito, M.; Tsuruo, T. Caspase-mediated cleavage of cytoskeletal actin plays a positive role in the process of morphological apoptosis. Oncogene 1999, 18, 2423-2430.

(28) Morzel, M.; Terlouw, C.; Chambon, C.; Micol, D.; Picard, B. Muscle proteome and meat eating qualities of Longissimus thoracis of "Blonde d'Aquitaine" young bulls: a central role of HSP27 isoforms. Meat Sci. 2008, 78, 297-304.

(29) Rasolofoharitseheno, H.; Mompi, W.; Boudida, Y.; Gagaoua, M. Highlighting the degradation of actin in Longissimus dorsi muscle of different species: bovine, ovine, caprine, poultry and freshwater fish. Br. Biotechnol. J. 2015, 7, 169-176.

(30) Birktoft, J. J.; Fernley, R. T.; Bradshaw, R. A.; Banaszak, L. J. Amino acid sequence homology among the 2-hydroxy acid dehydrogenases: mitochondrial and cytoplasmic malate dehydrogenases form a homologous system with lactate dehydrogenase. Proc. Natl. Acad. Sci. U. S. A. 1982, 79, 6166-6170.

(31) Lee, S. M.; Kim, J. H.; Cho, E. J.; Youn, H. D. A nucleocytoplasmic malate dehydrogenase regulates p53 transcriptional activity in response to metabolic stress. Cell Death Differ. 2009, 16, $738-748$.

(32) Fisher, A. B. Peroxiredoxin 6: a bifunctional enzyme with glutathione peroxidase and phospholipase A(2) activities. Antioxid. Redox Signal. 2011, 15, 831-844.

(33) Manevich, Y.; Shuvaeva, T.; Dodia, C.; Kazi, A.; Feinstein, S. I.; Fisher, A. B. Binding of peroxiredoxin 6 to substrate determines differential phospholipid hydroperoxide peroxidase and phospholipase A(2) activities. Arch. Biochem. Biophys. 2009, 485, 139-149.

(34) Martin, S. J.; Reutelingsperger, C. P.; McGahon, A. J.; Rader, J. A.; van Schie, R. C.; LaFace, D. M.; Green, D. R. Early redistribution of plasma membrane phosphatidylserine is a general feature of apoptosis regardless of the initiating stimulus: inhibition by overexpression of Bcl-2 and Abl. J. Exp. Med. 1995, 182, 1545-1556.

(35) Daugaard, M.; Rohde, M.; Jaattela, M. The heat shock protein 70 family: highly homologous proteins with overlapping and distinct functions. FEBS Lett. 2007, 581, 3702-3710.

(36) Vaughan, K. T.; Weber, F. E.; Ried, T.; Ward, D. C.; Reinach, F. C.; Fischman, D. A. Human myosin-binding protein $\mathrm{H}(\mathrm{MyBP}-\mathrm{H})$ : complete primary sequence, genomic organization, and chromospinal localization. Genomics 1993, 16, 34-40.

(37) Golenhofen, N.; Perng, M. D.; Quinlan, R. A.; Drenckhahn, D. Comparison of the small heat shock proteins $\alpha \mathrm{B}$-crystallin, MKBP, HSP25, HSP20, and cvHSP in heart and skeletal muscle. Histochem. Cell Biol. 2000, 122, 415-425.

(38) Lomiwes, D.; Hurst, S. M.; Dobbie, P.; Frost, D. A.; Hurst, R. D.; Young, O. A.; Farouk, M. M. The protection of bovine skeletal myofibrils from proteolytic damage post mortem by small heat shock proteins. Meat Sci. 2014, 97, 548-557.

(39) Wiedemann, N.; Frazier, A. E.; Pfanner, N. The protein import machinery of mitochondria. J. Biol. Chem. 2004, 279, 14473-14476.

(40) Mayer, M. P. Hsp70 chaperone dynamics and molecular mechanism. Trends Biochem. Sci. 2013, 38, 507-514.

(41) Kaul, S. C.; Deocaris, C. C.; Wadhwa, R. Three faces of mortalin: a housekeeper, guardian and killer. Exp. Gerontol. 2007, 42, 263-274.

(42) Glancy, B.; Balaban, R. S. Role of mitochondrial $\mathrm{Ca}^{2+}$ in the regulation of cellular energetics. Biochemistry 2012, 51, 2959-2973.

(43) Kinumi, T.; Kimata, J.; Taira, T.; Ariga, H.; Niki, E. Cysteine106 of DJ-1 is the most sensitive cysteine residue to hydrogen peroxide-mediated oxidation in vivo in human umbilical vein endothelial cells. Biochem. Biophys. Res. Commun. 2004, 317, 722-728.

(44) Clements, C. M.; McNally, R. S.; Conti, B. J.; Mak, T. W.; Ting, J. P. DJ-1, a cancer- and Parkinson's disease-associated protein, stabilizes the antioxidant transcriptional master regulator Nrf2. Proc. Natl. Acad. Sci. U. S. A. 2006, 103, 15091-15096.

(45) Sales, J.; Mellett, F. D. Post-mortem pH decline in different ostrich muscles. Meat Sci. 1996, 42, 235-238.

(46) Zigmond, S. H. Beginning and ending an actin filament: control at the barbed end. In Current Topics in Developmental Biology; Academic Press: San Diego, CA, USA, 2004; Vol. 63, pp 145-188.

(47) Priolo, A.; Micol, D.; Agabriel, J. Effects of grass feeding systems on ruminant meat colour and flavour. A review. Ann. Zootech. 2001, 50, 185-200.

(48) Gil, M.; Serra, X.; Gispert, M.; Angels Oliver, M.; Sanudo, C.; Panea, B.; Olleta, J. L.; Campo, M.; Olivan, M.; Osoro, K.; GarciaCachan, M. D.; Cruz-Sagredo, R.; Izquierdo, M.; Espejo, M.; Martin, M.; Piedrafita, J. The effect of breed-production systems on the myosin heavy chain 1, the biochemical characteristics and the colour variables of Longissimus thoracis from seven Spanish beef cattle breeds. Meat Sci. 2001, 58, 181-188.

(49) Gagaoua, M.; Durand, D.; Micol, D.; Santé-Lhoutellier, V.; Terlouw, C.; Ellies-Oury, M. P.; Boudjellal, A.; Hocquette, J. F.; Picard, B. Biomarkers of meat sensory qualities of Angus beef breed: towards the development of prediction equations. In 15èmes JSMTV; Viandes \& Produits Carnés: Clermont-Ferrand, France, 2014; pp 137-138.

(50) Carbone, D. L.; Doorn, J. A.; Kiebler, Z.; Sampey, B. P.; Petersen, D. R. Inhibition of Hsp72-mediated protein refolding by 4hydroxy-2-nonenal. Chem. Res. Toxicol. 2004, 17, 1459-1467.

(51) Sahara, S.; Yamashima, T. Calpain-mediated Hsp70.1 cleavage in hippocampal CA1 neuronal death. Biochem. Biophys. Res. Commun. 2010, 393, 806-811.

(52) Esterbauer, H.; Schaur, R. J.; Zollner, H. Chemistry and biochemistry of 4-hydroxynonenal, malonaldehyde and related aldehydes. Free Radical Biol. Med. 1991, 11, 81-128.

(53) Suman, S. P.; Faustman, C.; Stamer, S. L.; Liebler, D. C. Redox instability induced by 4-hydroxy-2-nonenal in porcine and bovine myoglobins at pH 5.6 and 4 degrees C. J. Agric. Food Chem. 2006, 54, 3402-3408.

(54) Ramanathan, R.; Mancini, R. A.; Suman, S. P.; Beach, C. M. Covalent binding of 4-hydroxy-2-nonenal to lactate dehydrogenase 
decreases $\mathrm{NADH}$ formation and metmyoglobin reducing activity. J. Agric. Food Chem. 2014, 62, 2112-2117.

(55) Harada, Y.; Sato, C.; Kitajima, K. Complex formation of 70-kDa heat shock protein with acidic glycolipids and phospholipids. Biochem. Biophys. Res. Commun. 2007, 353, 655-660.

(56) Mahalka, A. K.; Code, C.; Jahromi, B. R.; Kirkegaard, T.; Jaattela, M.; Kinnunen, P. K. Activation of phospholipase A2 by Hsp70 in vitro. Biochim. Biophys. Acta, Biomembr. 2011, 1808, 2569-2572.

(57) Zhang, M.; Wang, D.; Geng, Z.; Bian, H.; Liu, F.; Zhu, Y.; Xu, $\mathrm{W}$. The level of heat shock protein 90 in pig Longissimus dorsi muscle and its relationship with meat $\mathrm{pH}$ and quality. Food Chem. 2014, 165, 337-341.

(58) Tang, J.; Faustman, C.; Lee, S.; Hoagland, T. A. Effect of glutathione on oxymyoglobin oxidation. J. Agric. Food Chem. 2003, 51, 1691-1695.

(59) Renerre, M.; Labas, R. Biochemical factors influencing metmyoglobin formation in beef muscles. Meat Sci. 1987, 19, 151165.

(60) Picard, B.; Meunier, B.; Barboiron, C.; Dunoyer, N.; Guillemin, N.; Micol, D. From protein markers to phenotyping tools for evaluation of beef tenderness. In Farm Animal Proteomics; Rodrigues, P., Eckersall, D., Almeida, A., Eds.; Wageningen Academic Publishers: Wageningen, The Netherlands, 2012; pp 165-168. 